\section{BOLLETINO DELLA \\ SOCIETA CEOCRAFICA ITALIANA}

OPEN ACCESS

Citation: A. Bonazzi (2020). Bologna City

Branding. Bollettino della Società Geografica Italiana serie 14, 3 Special Issue: 63-71. doi: 10.36253/bsgi-992

Copyright: (c) 2020 A. Bonazzi This is an open access, peer-reviewed article published by Firenze University Press (http://www.fupress.com/bsgi) and distributed under the terms of the Creative Commons Attribution License, which permits unrestricted use, distribution, and reproduction in any medium, provided the original author and source are credited.

Data Availability Statement: All relevant data are within the paper and its Supporting Information files.

Competing Interests: The Author(s) declare(s) no conflict of interest.
Firenze University Press

www.fupress.com/bsgi

\title{
Bologna City Branding
}

\author{
Alessandra Bonazzi \\ Dipartimento di Filosofia e Comunicazione (FILCOM), Università degli Studi di Bolo- \\ gna, Italy \\ E-mail: alessandra.bonazzi@unibo.it
}

\begin{abstract}
The purpose of the article was to analyze the standardized city branding process that since 2014 has restructured the public space of Bologna and redefined the emotional territory of its citizens through the active remodeling or branding of urban policies. As is known, Bologna's global brand is based on the generative logo City of Food is Bologna (Bonazzi, Frixa 2019), which has re-generated the spaces of consumption by translating them according to the terms of contemporary documedial capital (Ferraris 2020; Semi 2015). However, the writing of this article has coincided with the latest stages of the Quarantine imposed by Covid-19 and the imminent start of socalled Phase 2. The unprecedented event of the pandemic has temporarily suspended the functioning of the current City of Food by placing the atmosphere of euphoric consumption in quarantine. In other words, a Landscape of Quarantine has critically overlapped that of the City of Food and revealed its fragility and crisis - which, however, was already made evident by the voracity with which branding had consumed its ethical potential (Arvidsson 2007). On the threshold of the quarantine, and waiting to understand the fate of the Bologna branding, the whole process has therefore been analyzed in the light of Jean Baudrillard's analytical categories relating to the "fourth, the fractal (or viral, or radiant) stage of value" (Baudrillard 2001a) and within the temporal torsion that is typical of the unexpected interference of any crisis.
\end{abstract}

Keywords: Landscape of Quarantine, urban space, city branding, food.

Riassunto. Lo scopo dellarticolo era analizzare il processo standardizzato di city branding che dal 2014 ha ristrutturato lo spazio pubblico di Bologna e ridefinito il territorio emotivo dei suoi cittadini mediante lattiva rimodulazione o brandizzazione delle politiche urbane. Comè noto il marchio globale di Bologna dipende dal logo generativo City of Food is Bologna (Bonazzi, Frixa 2019) che ha ri-generato gli spazi del consumo traducendoli secondo i termini del contemporaneo capitale documediale (Ferraris 2020; Semi 2015). Tuttavia, la stesura del presente articolo ha coinciso con le ultime fasi della Quarantena imposta dal Covid-19 e l'imminente avvio della cosiddetta Fase 2. L'inedito evento della pandemia ha temporaneamente sospeso il funzionamento dellattuale City of Food mettendone in quarantena l'atmosfera di consumo euforico. In altre parole, un Landscape of Quarantine si è criticamente sovrapposto a quello della City of Food e ne ha rilevato la fragilità e la crisi - già comunque evidenziata dalla voracità con la quale il branding aveva consumato il suo potenziale etico (Arvidsson 2007). Sulla soglia della quarantena, e in attesa di capire il destino del branding bolognese, l'intero processo è stato perciò analizzato alla luce delle categorie analitiche di Jean Baudrillard relative al "fourth, the fractal (or viral, or radiant) stage of value" (Baudrillard 2001a) e dentro la torsione temporale che è propria dell'imprevista interferenza di ogni crisi. 
Parole chiave: Paesaggio della quarantena, spazio urbano, city branding, cibo.
The fourth stage is the phase of viruses.

At that stage, we are in a fourth, viral dimension where resistance is no longer possible. What can you do then? Jean Baudrillard, Fragments

The secret is: "come over here and make it up, since it's the tourist himself who takes part in the narration". Roberto Grandi

\section{Landscape of Quarantine and "Viral Ontology": a necessary premise}

In 2010 Nicola Twilley and Geoff Manaugh curated an exhibition entitled "Landscapes of Quarantine". According to the two curators, spatial separation is presented as a strategic response to the suspicion. More precisely: "quarantine is a strategy of separation and containment - the creation of a hygienic boundary between two or more things, for the purpose of protecting one from exposure to the other. It is a spatial response to suspicion, threat, and uncertainty" ${ }^{\prime \prime}$ Now, ten years later in 2020, Covid-19 is suddenly staging an intense global Landscape of Quarantine, necessitating a worldwide crisis lockdown and torsion in a global "future-in-past" timeframe of quarantine, as it proceeds towards the viral restructuring of capital flows, consumption and narratives - including that of our social/individual bodies, simultaneously dangerous and endangered.

Covid-19, with the inevitable result of physical and moral quarantine, has presented itself as a truly global line of crisis capable of unhinging the last residue of apparent technical/immunological security - the dream of being able to control the infection - representing "the archetypal conflict that confronts public health: the tension between society's dual interests in safeguarding individual liberty while protecting and promoting the health of its citizens" (Ries 2004, 3).

Translated into the outcome of our research, this accelerated line of torsion or crisis has quarantined the dissonant geography of the Bologna City of Food genera-

\footnotetext{
${ }^{1}$ https://dprbcn.wordpress.com/2010/03/04/landscapes-of-quarantinecurated-by-geoff-manaugh-and-nicola-twilley/

2 The presentiment of a future of crises that comes from the past and from the margins is the form of thought proper to the crisis. See Derrida 1999.
}

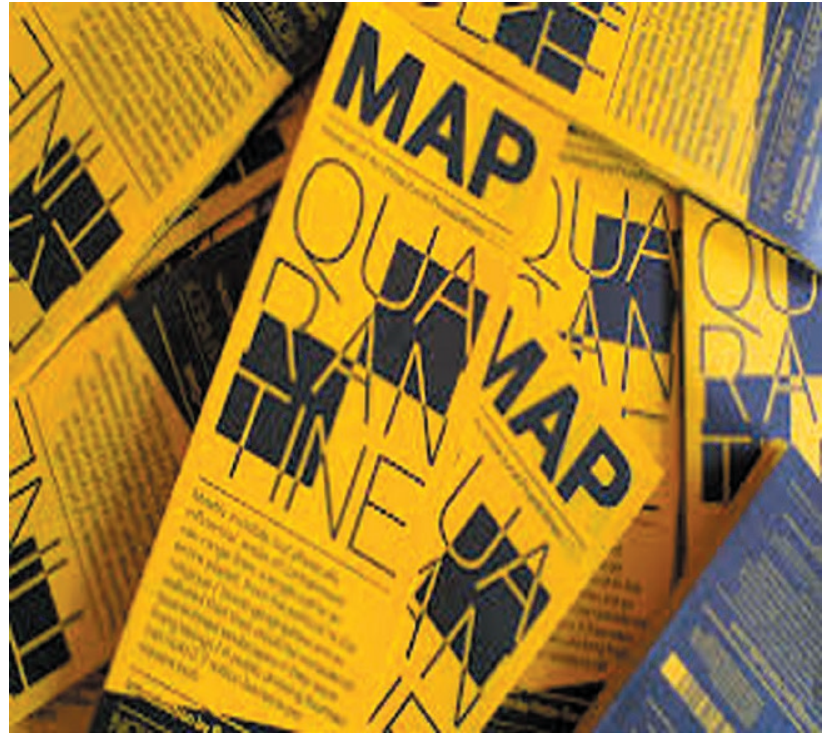

MAP 002: Quarantine by David Garcia
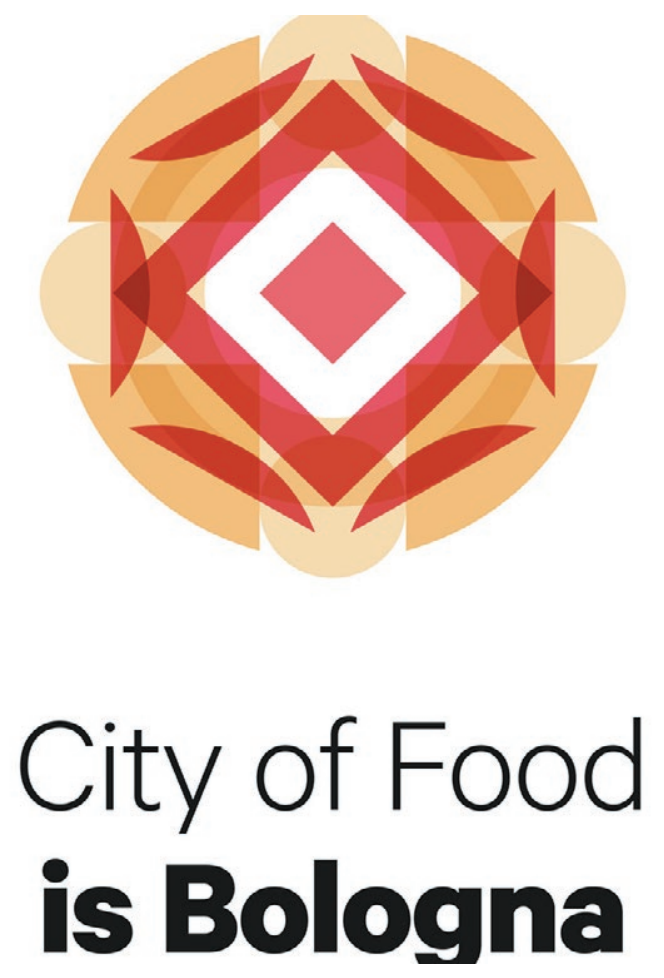

tive logo and the euphoric communication capital that animated its Brandscape (Vanolo 2017). Indeed, "the spatial response to suspicion, threat, and uncertainty" is clearly irreducible to the scenes of consumption in which, to paraphrase Peter Sloterdijk, the principle of availability for consumption is given in the form of signs 
and opportunities for contact. On the eve of the imminent reopening of the places of consumption and commerce (the so-called Phase 2), it is the imperative of the "security mechanism" (Lakoff 2017, 99-100) that dictates the geometry of social distancing: the renegotiation of quantitative terms in the relationship between space, sociality and consumption. This is what is happening in Bologna:

"The Mayor gathers the appeal by the handfulls, [...] promising for Phase 2 tables in place of the blue stripes. Will the Bolognese hosts be forced to reduce their seats due to social distancing? And will the City widen the spaces for the dehors, regardless of the size of the premises, even at the cost of sacrificing parking. "If a club has to reduce its seating by half - says the mayor - we'll ensure that throughout the summer season instead of the blue stripes there will be tables." As well as ensuring "all possible efforts to reduce city taxes".

The Councilor for Commerce Alberto Aitini points out: "We're currently working on the dehors in order to help out the merchants: we'll cater to the needs of everyone, those of the residents who have to go home, as well as those of pedestrians or cyclists who have to pass through" ("Repubblica Bologna" 04/30/2020).

But the geometry that increases the urban space assigned to the re/production of value doesn't take into account the emotional needs of Bologna's immaterial global City of Food branding and its typical scenes. So the obvious question that circulates among the tables is:

What will the City of Food be like next Monday, May 18th, [...]? Next Monday won't be the same as before. Forget the casual chatter at the Osteria del Sole, along with that Vicolo Ranocchi stunned by the evening crowd, where not even a pin could pass. Who knows if you can still meet people "by chance", if there will be "love at first sight", because it will be a scene "by reservation only". [...] Will you still be able to chat with the host, who in many cases has been a rare confidant? And all those yummy things in the form of canapes and finger food in residence at the counter, at aperitif time, along with a glass of wine, a chat and then off to the next stage of an endless evening? [...] In the meantime, while awaiting better times, the Bolognese restaurant world is being forced to reinvent itself. Reducing the place settings by half, annulling spontaneity, with the aggregation that turns inexorably into a gathering, the aperitif is transfigured into an Afternoon Tea, the defense of the tureen with tortellini, to be brought steaming hot to the table, is the daily exercise in this new social order where the possible arrival of plexiglass is announced as the end of the world, when taverns will become non-places like highway restaurants. The kitchens start up again, the dining service becomes more formal, hope lingers on and it is hoped, as all the restaurateurs in the shadow of the Two Towers say in chorus, "that the customers won't be afraid and will come back to grace our tables, because this state of affairs can't last forever". ("Repubblica Bologna", 14/05/2020, italics mine)

In other words, the calculation of urban social distancing activates in the City of Food the suspicion of viral and intangible contamination as an atmospheric principle (Sloterdijk 2013) which fatally contaminates, by sanitizing it, that euphoric atmosphere of consumption assigned to Foodatainment's own themes: the crowded sharing of experience and the hypersocialization/aestheticization of consumption (Finkelstein 1999). It's the formal, salutary strictness of social distancing on reservation and the insistence on physical boundaries - signs that deny any chance of contact - that makes manifest and upsetting the potential contagion process that "requires contact", but more subtly "it always implies more than this: it implies absorption, invasion, vulnerability, the breaking of a boundary imagined as secure, in which the other becomes part of the self" (Bashford, Hooker 2001, 4).

For now this is exactly where we are: on the cultural threshold of an impending crisis, in the expectation of a future-in-past that afflicts the political space of the Urban Landscape of Quarantine and infects the scenes of profit of the Bolognese Foodscape that oscillate between desire, circulation and "cognitive dissonances"3. And this torsion, this polysemic line of tension between control and profit - between biopolitics and bio-informational capitalism - is an interference that unites the multiple planes in which the two landscapes unfold. It can be called contagion, brand equity or, which is the same, "viral ontology"4. However, the principle of that "total metonymy", by nature viral, which, according to Jean Baudrillard, is the proper figure of the "fourth, the fractal (or viral, or radiant) stage of value", in which "there is no point of reference at all, and value radiates in all directions, occupying all interstices [...]. Properly speaking there is no law of value, merely a sort of epidemic of value", the fourth phase of a capitalism based precisely on the circulation and active production and

\footnotetext{
${ }^{3}$ The expression belongs to the Director-General of the International Committee of the Red Cross (ICRC) Yves Daccord, who claims that "The great danger of the present situation is the (cognitive) dissonance the virus creates - between personal risk, which is very low, and community risk, which is very high". The danger naturally lies in the fact that the natural tendency is to ignore the community risk line. Cit. in Klimburg, Faesen, Verhagen, Mirtl 2020, 5.

${ }^{4}$ On the viral form of the contemporary theoretical thought treated here, I refer the reader essentially to: Jameson 1997; Bardini 2011; Deleuze, Guattari 2011: in particular see chapter "1730: BecomingIntense, becoming-Animal, Becoming-Imperceptible"; Baudrillard 2001a; Braidotti 2002.
} 
sharing of a viral communication of value (Baudrillard $1993,5)$. In some ways, this critical torsion is also the immediate biological translation of the digital metaphor of the experience of our time: "going viral has come to refer to an infectious idea that replicates itself, like a real virus, spreading rapidly through online networks" (Fisher 2016, 117), touching bodies, affections and narratives. Just as "contagion" is also the sign of the repeated overcoming of vulnerable bodily boundaries which bears the name of biocapitalism (Bardini 2011).

It is on this threshold - between biology and technology, affections and experiences, bodies and value, containment and contagion - that research on the places of consumption in Bologna should recommence. The choice is whether to do this by starting from the idea of "Landscape of Quarantine", orienting oneself with David Garcia's MAP 002 - to wit Quarantine - or from the prismatic Foodscape, illuminated by the irresistible viral phase indicated by Jean Baudrillard. Whatever the position, it is nonetheless the current unfolding viral order, of capital or life touched by ghostly physical or moral quarantines, that with which the future geography will have to critically reckon. And it doesn't matter which version of the topic you choose.

\section{On the threshold: branding, "ethical capital" and food}

For now the version is Bologna City of Food's, and the reckoning will be made with the standardized order of value extraction in the form of emotion and available atmospheres, by way of the food theme - an ideal commodity because by its nature it's boundless. Such an order, which doesn't differ from the one Baudrillard theorized, requires the implementation of a standard procedure capable of crystallizing the aesthetic and cultural values of any city ${ }^{5}$.

The procedure doesn't reserve any surprises and always achieves the expected result. The standard rests on the projective lines of imagination and desire, causing the design of a precise, convincing image of the city. The image is based on the shared, participatory narrative of what makes it truly unique, by selecting and re-signifying denotative and connotative traits that seduce consumers

\footnotetext{
${ }^{5}$ The topic of urban regeneration through the global branding strategy usually has a strategic strong point in food (Semi 2015). In Bologna, food has become the exclusive object of potentially unlimited cultural consumption, the sign that has spatialized, recreated and absorbed all the urban social functions, lending itself to immediate consumption that falls within the cultural logics of contemporary communicative capitalism. The Bologna case is a good example of what Esperdy calls "Edible Urbanism" (Esperdy 2002).
}

and investors. The result is the production of a desire that the urban image externalizes and circulates, whose aesthetic, symbolic, experiential value is computed in relation to the stocks of current information capitalism.

The calculation of value obviously depends on the euphoric consumer atmosphere that the image suggests and on their coinciding with the expectations and desires disseminated online ${ }^{6}$. Hence, the calm that welcomes the progressive commercialization of the public space, the active symbolic construction of rigid codes of access to the practice and social use of this space isn't surprising, nor is the domestication of the antagonistic dimension of politics within the regeneration plan devised by the brand (Atkinson 2003; Eshuis, Klijn, Braun 2014). In other words, to extract value from the immaterial, symbolic dimension of the material consumption of cities, it is necessary to make urban policies "ghostly" (Vanolo 2017) and to push on the "phantasmagoric" dimension of the mediated sharing of emotions related to consumption (Andreotti, Lahiji 2017). Therefore urban branding prescribes three moves: the gentrification of crystallized spaces, the exploitation for profit of informational (Dyer-Withford 1999) or documedial capital (Ferraris 2018, 2020) to extract the so-called brand equity, the recourse to more advanced neoliberal governance and consultancy policy.

This global order of city branding has also engulfed Bologna since 2014, which, as is known, has been restructured as an "à la carte city" at the back and call of tourists, who choose according to their desire of the moment and are free to freely draw up their own menu. The principle of "total metonymy" is in action, and it is illusory to believe that it only affects urban forms, since citizens are the interface for creating brand value and part of what must be sold as lifestyle (Bookman 2014, 86). So it isn't out of place to resort to the suggestion of branding as a viral prismatic crystal, whose "value radiates in all directions, occupying all interstices", interweaving even our bodies. It's no coincidence that this is exactly what the City of Food - Eataly World (www. youtube.com/ watch? $v=$ ycKP9AKP72o) video delineates. Here, in fact, the logo reverberates and radiates onto every corner, surface, facade, floor and square of a nocturnal Bologna, poetically engaging the rare passersby. Needless to say, the values evoked by this contact take the form of food, immediately transformed into potential brand equity.

The reverberation of that sort of contact realizes what Peter Sloterdijk calls the contemporary psycho-

\footnotetext{
${ }^{6}$ For an exhaustive critical interpretation of the logic and practice of Branding, I refer the reader to Arvidsson 2006.
} 
geography of emotions redesigned by urban branding, whose content hinges on the idea of a "public interior" that absorbs and translates the space of merchandise into a mass total and comprehensive staging - internalized in the minds of consumers (Sloterdijk 2013). In a more pragmatic way and in the words of Adam Arvidsson:

Brand equity thus consists of a set of proprietary social relations. In this sense, brands are examples of social interaction made into capital, they are a form of "ethical capital". Consequently brand management is primarily about organizing such relations between the brand and its customers (and, increasingly, between customers by means of the brand). It is about managing the affective dimension of social interaction, making sure that a desired modality of interacting and relating arises. This way brand management is about [...] "affect modulation". Because brands work mainly to turn affect into value, they can give us a key insight into the growing economic importance of affect and "experiences" in the information economy (Arvidsson 2007, 10-11).

The emotional territory unfolds among the tables and the mediated social relationships, making possible the unfolding of ethical capital between shared narratives and the circulation of affects, placing Bologna at the top of the aestheticizing global food gentrification, according to the intentions of an economic order that regulates the "Immaterial productivity" that "tends to be increasingly socialized" (Arvidsson 2007, 7). What however was unpredictable has been the accelerated exhaustion of the equity brand, as a sign of the voracity with which symbolic capital has devoured the secret of the "à la carte city" (2014-2018) and engulfed the city. The fatal de-generation of the logo is one of the risks of the impact of routine contagion.

\section{The fourth stage of capitalism: "Documediality" and City of Food}

The report of the implementation of the Bolognese brand is edited by Roberto Grandi, scientific manager of the process, and Alice Prospero (Grandi, Prospero 2015). It's a narrative that makes clear the routine practice of urban branding, planned at each stage and characterized by the usual keywords - imagination, creativity, participation and belonging. The climate of public and private investment is the usual atmosphere that supports the political banner of strategic urban regeneration. Therefore the opening is assigned to Matteo Lepore (Councilor for the City's Economy and Promotion, Tourism,
International Relations and Digital Agenda from 2011 to 2016) $)^{7}$ :

So, first and foremost, the is Bologna project is an invitation to ourselves to reflect on what we are and what we would like to be; an invitation to be creative and to take a leading role, to look forward and not back, but without eradicating our roots (Grandi, Prospero 2015, 7).

In short, the promotion of Bologna's identity moves from the individual dimension and collective rewriting - the auto(bio)graphy of contemporary cities - of those terrains of the imagination that ensure the maximum value of the brand: to wit, equity. The whole question plays on the definition and communication of tangible and intangible identity attributes. Hence the invitation is to participate enthusiastically in the writing of a shared storytelling and an equally shared self-reflection. The outcome of

the process of construction of a brand is given by the image that the various reference publics have of the brand. If place marketing privileged the targets external to the city, to whose demands for places it tried to give adequate answers, place branding also keeps in mind the internal targets of the city" (Grandi, Prospero 2015, 11).

Perfectly in keeping with the principle of interiority identified by Sloterdijk, since each place branding depends on the construction of a perceived positive image, which produces and reinforces in the citizens a high sense of civic pride and belonging (political technique) and, externally, which is able to attract investors and tourists. The slide is towards the use of place branding as a subtly political protocol for governing, without conflict and in the desired direction, by participating in a project for the common good (Brenner 2002). We know what the objective is. In Roberto Grandi's words:

The overall proposal of the city, at the level of both tangible and intangible identity features, can be represented by the sentence "Bologna city à la carte", describing a city that does not offer fixed menus or combinations already predefined to choose between, but a plurality of proposals that the different types of public can freely choose in relation to their desires (Grandi, Prospero 2015, 37).

A concept that belongs to the gastronomic dimension - fixed menu and/or creative invention of the meal - where the choice between different offerings is best achieved in restaurants. Food extends itself to intangible

\footnotetext{
7 The city's current Councilor of Culture, Tourism, Promotion and Civic Imagination.
} 
traits, the only ones that play on experience and arouse emotion - transfuse urban manufacture, produce lifestyle, become the expected identity of Bologna - and the urban form extends itself instead to the metonymy of branding. This too is an expected and foreseen result. The last act is dedicated to the choice of the logo which can only be generative, since:

What emerged is a Bologna that does not put forward preconceived and inflexible itineraries, but a city that offers opportunities for choice and experimentation, both for those who are visiting for either short or long periods or for those who live here or come to the city every day. The Bologna that emerges is a city made up of many stories and a variety of ways of experiencing it which, in terms of visual representation, cannot be enclosed in the inflexible logos that traditionally characterise cities. This consideration led to an international competition being held to choose a new logo. As you browse the pages of this book you will see that this logo is presented as an alphabet which, based on symbols of the historical memory of our area, gives local institutions, businesses, associations and individuals the opportunity to describe their Bologna and to contribute to communicating its identity, which is at the same time plural, unique and distinctive. Thus the city is the product of what we think, what we experiment and of our way of life and the idea of opening ourselves up to this dimension using a new common alphabet is, in my opinion, fascinating (Grandi, Prospero 2015, 7).

The logo subtly prescribes restitution in the form of a personal narrative - a rhetorical appeal that stands for a creative and playful generative participation of equity to be introduced into euphoric ethical, informational capital $^{8}$. The public presentation of the City of Food project took place on March 24, 2014; on April $11^{\text {th }}$ the Mercato di Mezzo space opened to the public, and a few months later it was the Other space (Altro) of the Mercato delle Erbe (December 2014). Thus the city entered the stage of the fourth phase of capitalism - ethical, informational or viral - discovering the charm of an unlimited symbolic and material production of a commodity that lends itself to a practically unlimited consumption, that invades the body, touches the senses, activates the cultural imagination and the forms of sociality/conviviality. The atmosphere is inclusive and the homogeneity of gastronomic consumption is supported by the

\footnotetext{
${ }^{8}$ Matteo Bartoli and Michele Pastore won the competition by designing an alphabet of signs starting from some elements of Bologna's urban architecture. The letters make it possible to write any concept that generates a precise logo. Each word is accompanied by the is Bologna payoff. The web platform on which to write and share what Bologna is is naturally accessible to everyone. The detailed description can be found in Roberto Grandi's text.
}

repetition of the concept of experiential montage typical of Bologna's urban branding, publicly repeated as a mantra. A good example of how intangible productivity and brand equity extraction are truly, and increasingly, actively socialized and mediatized, "going viral". And the prismatic phantasmagoria of city branding begins its dance with Ghostly politics.

\section{City of Foodscape and brand (dis)equity}

The City of Food Manifesto (March 24, 2014) is the official and institutionalized acknowledgment of the project "devoted to metropolitan Bologna and the history of its love for food"9. To this object of desire is entrusted the "reputation of Bologna on a global level, a value to be protected and enhanced". The double meaning of this dedication, midway between values and value, which alludes to consumption and the public dimension of promotion (Gibson 2005, 260), is aimed at investors (public and private) who intend to participate in brand equity, including the entire urban community to which it proposes "to adopt the City of Food is Bologna brand and to work together". Having declared the theme of the composition of the "à la carte city", a clear, effective, and, should be added, predictable urban image is obtained. On the other hand, each brand works on the unambiguous clarity of its image, which doesn't preclude the multiplicity and variety of experiences that each of us can share by consuming the product, nor the heterogeneity of the experiential communities that are built around hypersocialization of the product's storytelling (Sepe, Pitt 2017, 3-4).

The first act of the generative logo acts on the toponym: City of Food stands for Bologna - it's what connotes the city - its meaning and monographic theme. Bologna, on the other hand, stands for the signifier that evokes in the imaginary the extension of all the food that can be found in the city, deploying and developing the urban space according to the prescriptions of the logo (Medway 2014, 155-156), up to internalizing the urban community - an active subject in reproducing and enhancing the love story with food as a decisive lifestyle. Incidentally, Bologna is also the global name of mortadella: a truly total metonymy that allows "same place and same time every emotional zoning experience" (Allingham 2008, 166). However, the crystallization generated by such a metonymy has accelerated the exhaustion of its brand value (2014-2018) and intensified the

\footnotetext{
${ }^{9}$ www.comune.bologna.it/news/city-food-il-progetto-di-marketing-territoriale-sul-cibo-che-guarda-allexpo-2015
} 
consumption of public space in a single direction. The voracity of branding, the prismatic touch of ethical capital, envelops the city in the order of the unfolding fourth phase. Sharon Zukin coined the term urbanoid as an attempt to say that the buying and selling of urban space doesn't principally concern portions of physical space but segments of the social one, by privatizing the traditional heterogeneous aspect of the streets, sociability and commerce (Jackson 2010). And it's here that the immaterial line of critical torsion that the promise of brand equity maintains becomes visible. It's all played on the line of desire for food - in the dual form of displayed merchandise and of circulating value in the hypersociality mediatized and mediated by commerce. The architectural installation is left intact, intensifying the emotional experience of the gastronomic spectacle and removes the presence of those who, in some way, interrupt the internal atmosphere of euphoric moral relief. The values of the spiritual market of brand equity, exchanged on the table of the security and aestheticization of consumption, require the inevitable social (dis)equity of exclusion or quarantine (Low, Smith 2005). It also affects those who don't participate in the storytelling or share the symbolic code in operation.

The order of branding stages forms of hospitality and welcome that support and enhance that image of conviviality expected by the tourist and conveyed by the brand theme (Graziano 2013). Of course, the street, the market are public spaces par excellence, and some intrusion or dissonance is always possible, but in the interior world of ethical capital, the very hard contemporary symbolic economy is at work. Therefore, the urbanoid belongs by rights to a particular sector of public. Because it is no longer simply a matter of places where you can eat or socialize, but landscapes of the "City of Food" populated by members of the emerging creative class and those of a more traditional middle class, which however have an extraordinary appetite (Bookman 2014). Two steps into the urban phantasmagoria and you learn what happens to the values of hospitality, welcoming and sociability when they are touched by value (brand equity) and internalized in the ethical capital of the emotional heritage of each successful brand (Bell 2007; Williams 2000; Neal 2006; Atkinson 2003). Here is where documedia capital plays its hand. While money informs about the purchasing power of subjects within the landscape - decidedly limited information - it is the narratives on social media that provide information on what you are, want, hopefully, intend to try - definitely unlimited amount of available information capital. Hence, the homogeneity of the expected image is built a priori by (and for) an exclusive public community that exclusively colonizes the urban space in an imaginary emotional territory of signs to be accumulated and put into circulation, made up of affections, views and experiences. The viral fractal ontology of urban regeneration carries out and replicates imaginaries, whose style changes to occupy every interstice and fold. For their part, the Bolognese are seduced by the symbolic system of the Foodscape, and few evade the media-based hypersocialization of breakfasts or aperitifs. The new middle class, creative or presumed such, takes its place at the tables, participating in the euphoric public conviviality. In short, everyone takes very seriously their routine work as re-producers of documedia capital, intensifying attractivity and desire within the urbanoid (Semi 2015, 101). At least until 2018.

\section{Implosion}

According to Jean Baudrillard the fractal stage is characterized by the retreat of the entire substance of the symbolic order of the third phase onto the current network of social value - or on the social network of value. This retreat, or the return of what was believed to be past, haunts the current economy of value, which therefore becomes pure simulation, in which codes and objects are ordered by the principle of contiguity without any reference to reality. The "City of Food" place branding is part of this hauntology, which presents itself as the return of the sign (indeed, the logo) now transformed into an object, but an object that isn't real, "an object much further removed from the real than the sign itself" (Baudrillard 2001b, 129). For Baudrillard, such an object outside of representation is "a fetish". For us here it's an urbanoid. An urbanoid filled with value. The last torsion is obvious: "when the passion for value becomes embodied, beyond value ... this becomes the object of a higher fetishism" (Baudrillard 2001b, 129). Marx's definition of fetishism as "the religion of sensuous appetites" (Raines 2002, 33) fits the City of Food like a glove. The degree of this higher fetishism or sensuous appetites is quantified by the numbers of the Chamber of Commerce: at the end of September 2017, there were 411 restaurants in the historic center in Bologna, 214 food takeaways, and 70 pastry and ice cream shops. The figure reached 1,420 , by adding the bars. Added to this total were 552 activities related to the food trade. The calculation is quickly made: for every 37 residents there was a space devoted to food. On an economic level, the yield stopped for all 12 months of 2018 - even if only by $0.9 \%$. City of Food closed 187 retail businesses and opened 247 food companies. The intense acceleration of the brand- 
ing process (in five years $+31.9 \%$ of restaurants, minimarkets $+48 \%$, cafeterias $+233 \%$ ) collides with the function and limits of the urban space, whose every fold and crevice has been fatally touched by it. On these limits, the euphoric narrative consumes value in the emotional market of experience: the creative "à la carte" city, in four years retreated into being a fixed price folding menu, whose presence on the net was reduced to $4 \%$. The urbanoid imploded. In the interior world of ethical capital, the atmosphere was oppressed by a negative semantic drift, and the emotional re-territorialisation, in order to retain brand equity - now decisively declining became a matter of internal consensus. "Thus the system is better seen as a kind of virus [...], and its development is something like an epidemic (better still, a rash of epidemics, an epidemic of epidemic)" (Jameson 1999, 249). If we adopt Fredric Jameson's standpoint, we see from there that Bologna City of Food has fulfilled the premises of the system and played in its logic.

"What can you do then?"

\section{References}

Allingham, P. (2008). Urban Space, Representation, and Artifice. Knowledge, Technology \& Policy, 3, 163-174. DOI: $10.1007 / \mathrm{s} 12130-008-9061-9$

Andreotti, L., Lahiji, N. (2017). The Architecture of Phantasmagoria: Specters of the City. London and New York, Routledge.

Arvidsson, A. (2006). Brands. Meaning and Value in media culture. London and New York, Routledge.

Arvidsson, A. (2007). The Logic of the Brand. Quaderni del Dipartimento di Sociologia e Ricerca sociale, 7-32.

Atkinson, R. (2003). Domestication by Capuccino or a Revenge on Urban Spaces? Control and Empowerment in the Management of Public Spaces. Urban Studies, 9, 1829-1843. DOI: 10.1080/0042098032000106627

Bardini, T. (2011). Junkware. Minneapolis, University of Minnesota press. https://www-jstor-org.ezproxy.unibo.it/ stable/10.5749/j.ctttsp7b.1

Bashford, A., Hooker, C. (Eds.) (2001). Contagion: Historical and Cultural Studies. London, Routledge, https://doiorg.ezproxy.unibo.it/10.4324/9780203453087

Baudrillard, J. (1993). The Transparency of Evil. Essays on Extreme Phenomena. London-New York, Versus.

Baudrillard, J. (2001a). Fragments: Conversation with Francois L'Yvonnet. London, Routledge.
Baudrillard, J. (2001b). Impossible Exchange. New York, Verso.

Bell, D.H. (2007). The hospitable city: social relations in commercial spaces. Progress in Human Geography, 1, pp.7-22. DOI:10.1177/0309132507073526

Bonazzi, A., Frixa, E. (Eds.). (2019). Mercati storici, rigenerazione e consumo urbano. Il caso di Bologna. Milano, Franco Angeli.

Bookman, S. (2014). Brands and Urban Life: Speciality Coffee, Consumers, and the Co-Creation of Urban café Sociality. Space and Culture, 17 (1), 85-99. https://doi-org. ezproxy.unibo.it/10.1177\%2F1206331213493853

Braidotti, R. (2002). Metamorphoses: Toward a Materialist Theory of Becoming. Cambridge, Polity Press.

Brenner, N.T. (2002). Spaces of Neo-liberalism: Urban Restructuring in North America and Western Europe. Melden, Blackwell.

Deleuze, G., Guattari, F. (2011). A Thousand Plateaus. Capitalism and Schizophrenia. New York, Continuum.

Derrida, J. (1999). Marx \& Sons. In Sprinker, M. (Ed.). Ghostly Demarcations: A Symposium on Jacques Derrida's "Specters of Marx". London, Verso, 213-269.

Dyer-Withford, N. (1999). Cyber-Marx: Cycles and Circuits of Struggle in High technology Capitalism. Urbana and Chicago, University of Illinois Press.

Eshuis, J., Klijn, E., Braun, E. (2014). Place marketing and citizen participation: branding as strategy to address the emotional dimension of policy making?. International review of Administrative Sciences, 1, 151-171. https://doiorg.ezproxy.unibo.it/10.1177\%2F0020852313513872

Esperdy, G. (2002). Edible Urbanism. Architectural Design, 72, 44-50.

Ferraris, M. (2018). Il capitale documediale. Prolegomeni. In Ferraris, M., Paini, G. (Eds.). Scienza Nuova. Ontologia della trasformazione digitale. Torino, Rosenberg\&Sellier.

Ferraris, M. (2020). From capital to Documediality. In Andina, T., Bojanić, P. (Eds.). Institutions in Action, Studies in the Politics of Sociality. Cham, Springer, 107-121. https://doi.org/10.1007/978-3-030-32618-0

Finkelstein, J. (1999). Foodatainment. Performance Research, 1, 130-136.

Fisher, T. (2016). Designing Our Way to a Better World. Minneapolis, University of Minnesota Press.

Gibson, T.A. (2005). Selling City Living. Urban Branding Campaigns, Class Power and the Civic Good. Inter- 
national Journal of Cultural Studies, 3, 259-280. DOI: $10.1177 / 1367877905055678$

Grandi, R., Prospero, A. (2015). È Bologna. Progetto City Branding. Bologna, Urban Center.

Graziano, T. (2013). Dai migranti ai turisti. Gentrification, luoghi del consumo e modelli di fruizione nelle città globali. Roma, Aracne.

Jackson, P. (2010). Food Stories: Consumption in an Age of Anxiety. Cultural Geographies, 1, 147-165. DOI: 10.1 177/1474474010363844

Jameson, F. (1997). Culture and Finance Capital. Critical Inquiry, 24 (1), 246-265. https://www.jstor.org/stable/1344165

Klimburg, A., Faesen, L., Verhagen, P., Mirtl, P. (2020). Pandemic Mitigation in the Digital Age: Digital Epidemiological Measures to Combat the Coronavirus Pandemic. Hague Centre for Strategic Studies \& The Austrian Institute for European and Security Policy. DOI: 10.2307/ resrep24010.1

Lakoff, A. (2017). Unprepared. Global Ealth in a Time of Emergency. Oakland, University of California Press. https://www.jstor.org/stable/10.1525/j.ctt1rfsrwc

Low, S., Smith, N. (Eds.) (2005). The politics of public space. London, Routledge. https://doi-org.ezproxy.unibo. it/10.4324/9780203390306

Mcqueen, S. (2016). Deleuze and Baudrillard. From Cyberpunk to Biopunk. Edinburgh, Edinburgh University Press. https://www.jstor.org/stable/10.3366/j.ctt1bh2k8h.1

Medway, D. (2014). What's in a name? Place branding and toponymic commodification. Environment and Planning A, 1, 153-167. DOI: 10.1068/a45571

Neal, Z. (2006). Culinary deserts, gastronomic oases: a classification of US cities. Urban Studies, 1, 1-21. http:// dx.doi.org.ezproxy.unibo.it/10.1080/00420980500388728

Raines, J. (Ed.) (2002). Marx on Religion. The Leading Article of No. 179 of Kölnische Zeitung (1842). Philadelphia, Temple University Press, 44-69.

Ries, N.M. (2004). Public health law and ethics: Lessons from SARS and quarantine, Health Law Review, 1, 3-6.

Semi, G. (2015). Gentrification. Tutte le città come Disneyland? Bologna, il Mulino.

Sepe, M., Pitt, M. (2017). Urban branding and place as a quality product: innovations in the urban experience. Journal of Facilities Management, 2-14. https://doi-org. ezproxy.unibo.it/10.1108/JFM-10-2016-0042
Sloterdijk, P. (2013). In the World Interior of Capital: Towards a Philosophical Theory of Globalization. Cambridge, Polity.

Vanolo, A. (2017). City Branding: The Ghostly Politics of Representation in Globalising Cities. New York and London, Routledge. https://doi-org.ezproxy.unibo. it/10.4324/9781315660660

Williams, A. (2000). Consuming hospitality: learning from post-modernism? In Lashley, C., Morrison, A. (Eds.). In search of hospitality: theoretical perspectives and debates. Oxford, Heinemann, 217-234. 